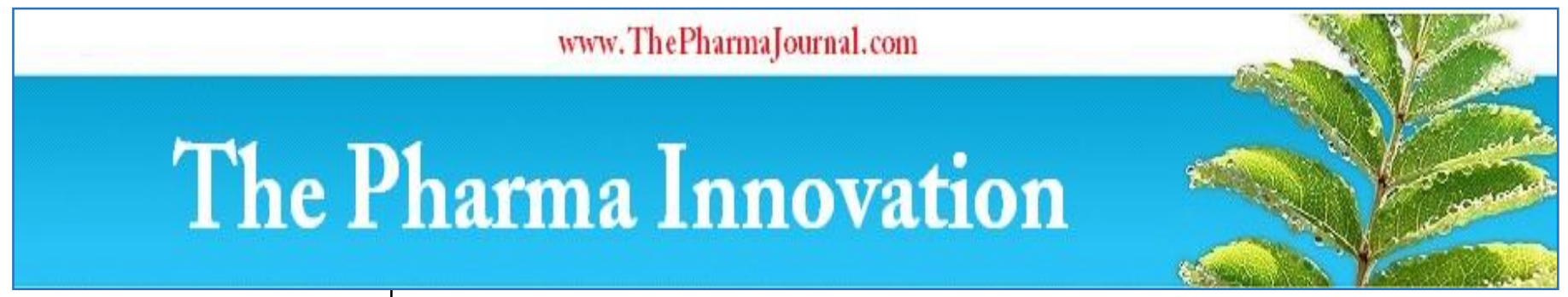

ISSN (E): 2277 - 7695

ISSN (P): 2349-8242

NAAS Rating: 5.03

TPI 2020; 9(6): 239-242

(C) 2020 TPI

www.thepharmajournal.com

Received: 08-04-2020

Accepted: 10-05-2020

Nikunjkumar Chauhan

M.Tech in Irrigation and drainage engineering, Godhra, Gujarat, India
Corresponding Author: Nikunjkumar Chauhan M.Tech in Irrigation and drainage engineering, Godhra, Gujarat, India

\section{Initial spreading of COVID-19 in Indian territory}

Nikunjkumar Chauhan

DOI: https://doi.org/10.22271/tpi.2020.v9.i6d.4774

\section{Abstract}

The coronavirus COVID-19 pandemic is one of greatest thread caused by a virus which was first seen in china Wuhan city. Geographical Information System (GIS) provides excellent means for visualizing and analyzing epidemiological data, revealing trends, dependencies and inter-relationships. This research includes the use of GIS visualization of spreading of COVID- 19 in Indian districts. Research concluded that the COVID-19 virus has superior ability to cover diseases area in lesser time. On date 30 April 2020 in the India $58.46 \%$ districts ware becomes affected by COVID-19 virus. Area with higher population density ware more af- fected. COVID-19 should be taken as serious diseases and people must support authorities in preventing spreading. In future, more precautions should be taken in preventions any viral dis- eases.

Keywords: COVID-19, corona, pandemic, GIS, India.

\section{Introduction}

The coronavirus COVID-19 pandemic is one of greatest thread caused by a virus which was first seen in china Wuhan city. The World Health Organization declared the spreading of COVID-19 as a pandemic on 11 March $2020^{[1]}$. As on date 19 May 19, 2020 world reach to 4,926,566 COVID-19 cases and having 320,892 death [2]. India is county having the second highest population reported its first COVID-19 case on 30 January $2020^{[3]}$. On the date 19 May 2020 India shows 58802 active cases, 39173 cured and 3163 deaths ${ }^{[4]}$. According to WHO scientific brief, the COVID-19 virus shows that it is primarily transmitted between people through respiratory droplets and contact routes ${ }^{[5] .}$

Geographical Information System (GIS) provides excellent means for visualizing and analyzing epidemiological data, revealing trends, dependencies and inter-relationships ${ }^{[6]}$. The discipline of medical geographic information systems provides a strong framework for our increasing ability to monitor these diseases and identify their causes. The GIS helps in understanding the spreading of diseases which may help in preventions measurers. Information about no of cases increasing in a particular area helps in analysis of hot sports zones. GIS also helps in proper utilization of human resources during an pandemic by analysis them. The research aims to help in understating of Spreading of Covid-19 virus in the Indian districts.

\section{Material and methods}

\section{Description of study area}

An Asian county India was selected as a study area. India is location lies between the northern hemisphere and eastern hemisphere. It has coordinates of latitudes $84^{\prime} \mathrm{N}$ to $37^{\circ} 6^{\prime} \mathrm{N} \& 68^{\circ} 7^{\prime} \mathrm{E}$ to $97^{\circ} 25^{\prime} \mathrm{E}$ longitude. India has a geographical area of 3,287,263 $\mathrm{km} 2$ which is divided into 28 states and 739 districts. India most important county needed to study for Covid-19 virus because is having the second highest population after china.

\section{Data acquisition}

Table 1. Table for various data sources.

\begin{tabular}{|c|c|c|c|}
\hline S. No. & Data type & Source & Description \\
\hline 1. & No of Covid-19 Patents & covid19india.org & $\begin{array}{c}\text { It provides latest information about Covid-19 } \\
\text { patents using various authen- tic sources }\end{array}$ \\
\hline 2. & No of Covid-19 Patents & mohfw.gov.in & $\begin{array}{c}\text { Indian Government official website of Covid- } \\
19 \text { patents information. }\end{array}$ \\
\hline
\end{tabular}




\section{Software}

ArcGIS 10.3 software of geographical information system was used for geo-spatial analysis and Geo-visualization of the data. It was utilized for making and utilizing maps, compiling ge- ographic information, analyzing mapped data, sharing and finding geographic data, utiliz- ing maps and geographic data in a extend of applications, and overseeing geographic data in a database. The shapefile of India with states and district boundary was used for analysis.

\section{Result and discussions}

First case of COVID-19 was seen in karela state in Thrissur district on 30 January 2020. After that on 13 February 2020 another two cases ware seen in Kasaragod and Alappuzha district of same state Karela. Further, there was no father increase in COVID - 19 cases till the 28 February 2020. 13 March 2020 number of cases ware reach to 97. After words, many passengers who ware reach to India from other countries started to shows COVID-19 symptoms and cases ware father increased. On basic of locations analysis, it shows that districts with higher pollution density show more cases of COVID-19.
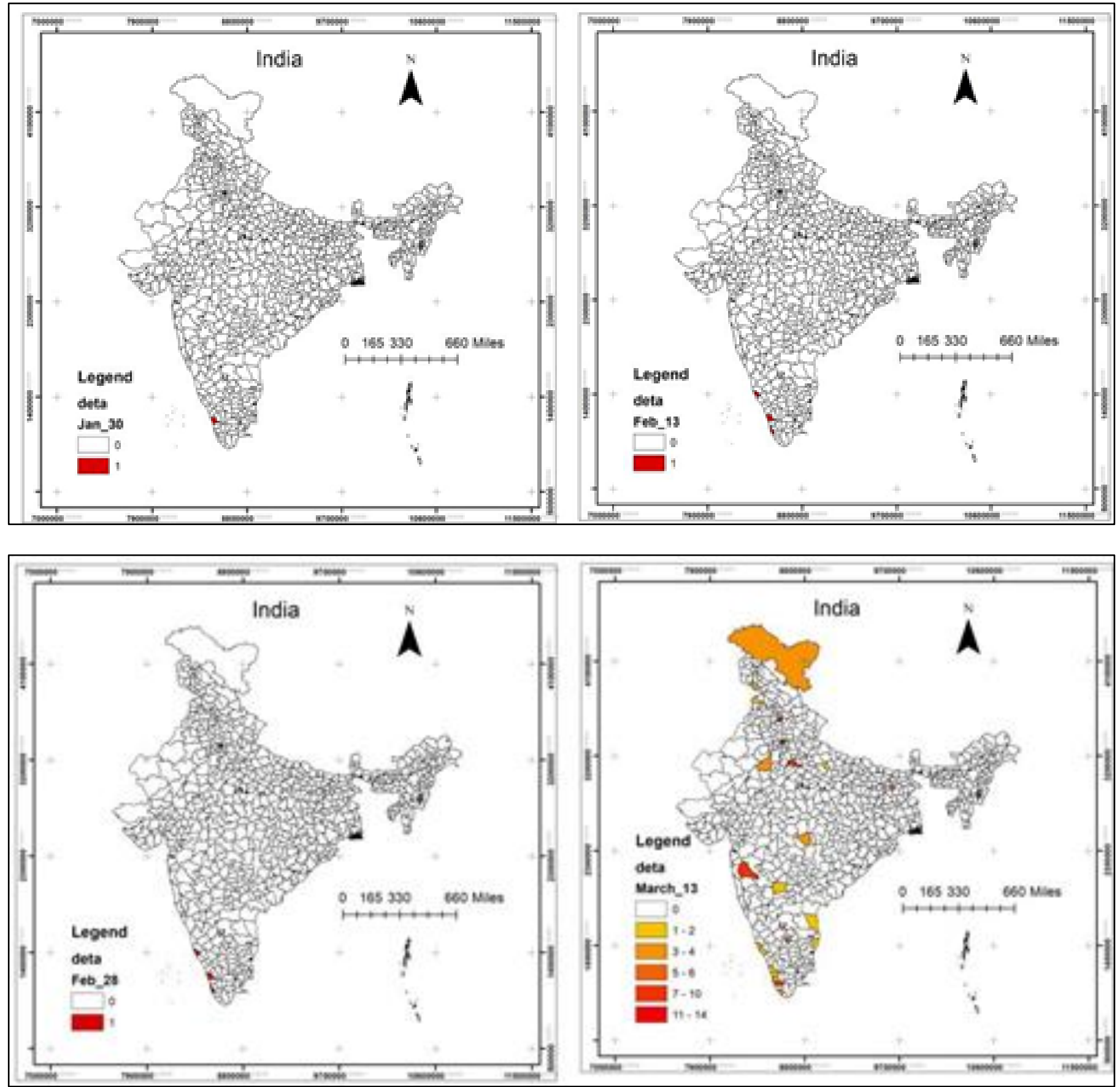


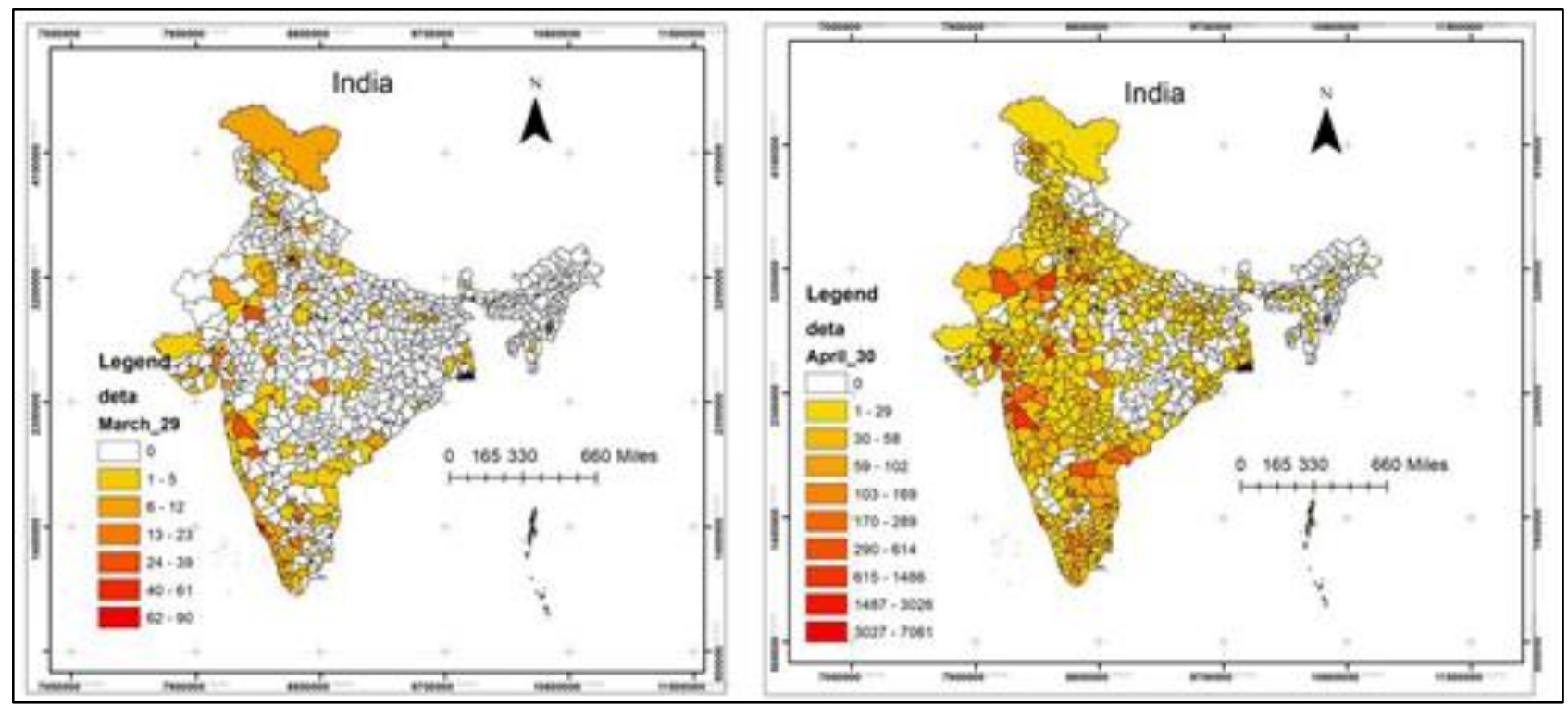

Fig 1: Districts vise spreading of COVID-19 from 30 January to 13 April 2020

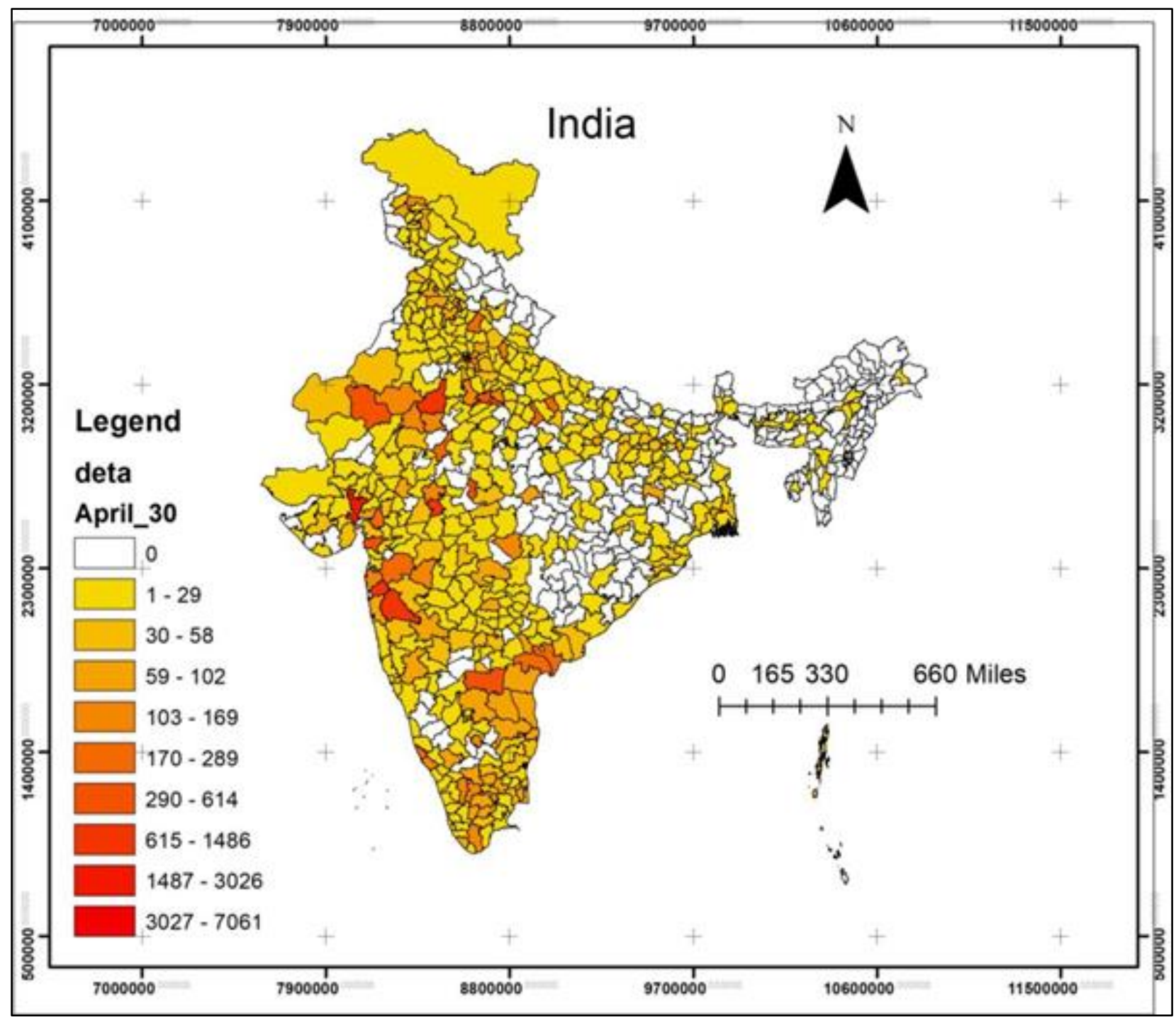

Fig 2: Districts confirmed of cases COVID-19 on 30 April 2020

Indian government decided to lock down the whole county from 22 March 2020. There was

649.485\% increase in Covid-19 cases till 29 March 2020 and the number of cases reaches to $727.1326 .54 \%$ increase occurred when no of cases reaches to 10371 till 13 April 2020 which ware further increase to 34339 cases on date 30 April 2020. During 13 April to 30 April 2020, there was only 231.106\% increased. On 30 April 2020 Mumbai, Ahmedabad and Delhi ware become the most affected area having high population density. 
Research concluded that the COVID-19 virus has superior ability to cover diseases area in lesser time. Area with higher population density ware more affected. On date 30 April 2020 in the India $58.46 \%$ districts ware becomes affected by COVID-19 virus. COVID-19 should be taken as serious diseases and people must support authorities in preventing spreading. In future, more precautions should be taken in preventions any viral diseases.

\section{Acknowledgements}

I would like thank to Kaushal Gadaria for support and inspiration I thank the department of soil and water conservation and department of irrigation and drainage, college of agricultural engineering and technology for providing the ArcGIS software in the framework of research. I would also like to thank Dr. Mukesh Tiwari (Assistant Professor \& Head, Dept. of IDE, CAET, Godhra, Gujarat) for support. I would acknowledge the anonymous reviewers for their valuable comments, suggestions and assistance in the improvement of the paper.

\section{References}

1. World Health Organization, WHO Timeline - COVID19. (2020). Url:

https://www.who.int/news-room/detail/27-04-2020-whotimeline---covid-19

2. Worldometer, COVID-19 Coronavirua pandemic, (2020). Url: https://www.worldometers.info/coronavirus/

3. Indiatoday news, Url: https:/www.indiatoday.in/india/story/kerala-reports-firstcon- firmed-novel-coronavirus-case-in-india-16415932020-01-30

4. Ministry of Health and Family Welfare, COVID-19 INDIA, Url: https://www.mohfw.gov.in/

5. World Health Organization, Modes of transmission of virus causing COVID-19, Url:

https://www.who.int/news-

room/commentaries/detail/modes-of-transmission-ofvirus- causing-covid-19-implications-for-ipc-precautionrecommendations

6. Georage JM, Chiang P, Tyler S, Rachel B, William K, Bereketab L et al. Use of GIS Mapping as a Public Health Tool- From Cholera to Cancer. Health Services Insights. 2013; 6:111-116.

7. Li, Y., Zhang, J., Wang, N., et al. (2020) Therapeutic Drugs Targeting 2019-nCoV Main Protease by HighThroughput Screening. https://doi.org/10.1101/2020.01.28.922922

8. Read JM, Bridgen JRE, Cummings DAT et al. Novel Coronavirus 2019- nCoV: Early Estimation of Epidemiological Parameters and Epidemic Predictions, 2020. https://doi.org/10.1101/2020.01.23.20018549

9. Li Q, Guan X, Wu P et al. Early Transmission Dynamics in Wuhan, China, of Novel Coronavirus-Infected Pneumonia. New England Journal of Medicine, 2020.

10. Riou J, Althaus CL 2020. Pattern of Early Human-toHuman Transmission of $\mathrm{Wu}^{-}$han 2019 Novel Coronavirus (2019-nCoV), December 2019 to January 2020. Eurosurveil- lance, 25, 2000058. https://doi.org/10.2807/1560-7917.ES.2020.25.4.2000058

11. Tang $\mathrm{B}$, Wang $\mathrm{X}$, Li $\mathrm{Q}$ et al. Estimation of the Transmission Risk of the 2019- nCoV and Its Implication for Public Health Interventions. Journal of Clinical Medicine. 2020; 9:462. https://doi.org/10.3390/jcm9020462 